commercial scale." Prepared by the above method, mannitol should be even cheaper than glycerol, if the residues are utilized as cattle feed, and would serve as a new source for the manufacture of explosives.

\title{
Summary.
}

I. Mannitol is a normal constituent of corn silage and of silage made from other plants containing sucrose.

2. It is formed in silage fermentation by bacterial reduction of the fructose-half of the sucrose molecule.

3. It is produced in considerable amount simultaneously with the acetic acid, lactic acid, carbon dioxide and alcohol, the characteristic constituents of silage, then part of it disappears.

4. Its presence accounts in large measure for the deficit noted when the sum of these products is balanced with the fermented sugar.

5. The possible industrial utilization of mannitol from silage is pointed out.

AMES, IOWA.

[CONTribution from the Chemistry Section, IOWA Agricultural, EXPERIMENT STATION.]

\section{THE OCCURRENCE OF $l$-LEUCINE IN SWEET CLOVER SILAGE.} By G. P. Platsance.

Received July 9, 1917.

The preceding paper contains data on the occurrence of mannitol in various kinds of silage. This substance was readily isolated from silage made not only from corn but also from cane and sunflower. However, no trace of mannitol could be found in the sample of sweet clover silage examined.

Unlike the other legumes, such as alfalfa and clover, sweet clover (Melliotus alba) can be ensiled without the addition of other plants to supply fermentable sugar. Sweet clover silage is at present little known. The examples examined by the writer were kindly furnished by Mr. Roy C. Bishop, County Agent of I,ivingston Co., Ill., who has had some experience with sweet clover silage and predicts a future for it in the Middle West.

When the samples were subjected to our usual process for the isolation of mannitol, no evidence whatever of this substance was found. Instead, a white substance crystallized in little round masses, which had altogether different properties from mannitol. On recrystallization from dilute alcohol, the product was obtained in snow-white, flat, scaly crystals. Some $18 \mathrm{~g}$. of the substance were obtained from sweet clover silage by the following treatment:

The silage was first dried on a steam box, then ground in a spice mill. The dry product was extracted ten hours with $95 \%$ alcohol in a continuous 
extractor. On evaporation of the extract the peculiar crystals already referred to were obtained, and then purified by recrystallization.

Analysis of the product gave the following results:

\begin{tabular}{|c|c|c|c|c|}
\hline \multirow[b]{2}{*}{ C } & \multicolumn{3}{|c|}{ Found. } & \multirow{2}{*}{$\begin{array}{c}\text { Calc. for } \mathrm{C}_{6} \mathrm{H}_{13} \mathrm{NO}_{2} \\
54.92\end{array}$} \\
\hline & $54 \cdot 78$ & 54.34 & 55.14 & \\
\hline $\mathrm{H} \ldots \ldots \ldots$ & 9.88 & 9.50 & 9.99 & 9.99 \\
\hline N......... & 10.78 & I0. 78 & Io. 85 & I0. 69 \\
\hline $\mathrm{NH}_{z}-\mathrm{N}$ (Sörensen) & 10.79 & 1079 & $\ldots$ & 10.69 \\
\hline
\end{tabular}

The figures agree closely with those calculated for leucine. The substance was then further identified by its specific rotation and by the properties of its benzoyl derivatives.

A $5 \%$ solution of the substance in $20 \% \mathrm{HCl}$ (sp. gr. I. Io) was examined in the polariscope. The average of six readings was $+2.3^{\circ} \mathrm{V}$.

$$
[\alpha]_{D}=+15.9^{\circ} .
$$

The specific rotation of $l$-leucine in $\mathrm{HCl}$ as reported by Fischer is $+15.8^{\circ}$.

The benzoyl derivative melted at $109^{\circ}$ and contained $5.89 \% \mathrm{~N}$; theory for benzoylleucine, $5.96 \% \mathrm{~N}$.

In the samples of sweet clover silage examined, the amount of leucine recovered ranged from 0.4 to $1.0 \%$ of the dry material. Leucine has not been obtained by the writer from any sample of corn silage, nor has its occurrence in silage been reported by any previous investigator.

AMEs, IOWA.

\section{PRESENCE OF NITRITES AND AMMONIA IN DISEASED PLANTS.}

\section{OXIDASES AND DIASTASES; THEIR RELATION TO THE DISTURBANCE.}

By P. A. Bonceutr and Mary Bonceutr.

Received June 14, 1917.

In a previous paper ${ }^{1}$ it was said that in certain plant diseases of the socalled physiological type such as Curly Top, ${ }^{2}$ also called Curly Leaf of sugar beets, Curly Dwarf of potatoes, Mottled Leaf of the potatoes, ${ }^{3}$ Mosaic disease of the tobacco, nitrites and ammonia were detected in the extracted juices. The origin of this nitrite and ammonia was supposed to be the absorbed nitrates from the soil. The reduction of these nitrates in the plant tissues was supposed to be caused by bacterial action from the fact that the presence of nitrate-reducing bacteria in the plant tissues run parallel with the presence of nitrites and ammonia in diseased plants. In this paper some more facts about the same diseases are re-

1 This JoUrnal, 38, 2572 (1916).

2 E. D. Ball, U. S. Dept. Agr., Bur. Ent., Bull. 66 (rgog); C. O. Townsend, U. S. Dept. Agr., Bur. Plant. Ind., Bull. 122 (1908).

${ }^{3}$ W. A. Orton, U. S. Dept. Agr, Bur. Plant Ind., Bull. 277; F. C. Stewart, New York Agr. Expt. Sta., Bull. 422. 